\title{
Pollutant Removal Abilities of Horizontal Subsurface Flow Constructed Wetland
}

\author{
Amit Kumar Maharjan ${ }^{a}$, Iswar Man Amatya ${ }^{b}$, Tadashi Toyama ${ }^{c}$ \\ a Integrated Graduate School of Medicine, Engineering and Agricultural Sciences, University of Yamanashi, Japan \\ b Department of Civil Engineering, Pulchowk Campus, Institute of Engineering, Tribhuvan University, Nepal \\ c Graduate Faculty of Interdisciplinary Research, University of Yamanashi, Japan \\ Corresponding Email: a amit_kmr@hotmail.com
}

\begin{abstract}
With the rapid urbanization, the production of wastewater is increasing day by day. Direct discharge of wastewater in the water bodies/land causes environmental pollutions. Hence, treatment of the wastewater is must, prior to the disposal. Treatment of wastewater through constructed wetlands (CWs) require low cost, less energy consumption, easy construction, and simple operation/maintenance. So, CWs can be the better option for the developing countries such as Nepal. Main objective of the study was to determine the pollutant/nutrient removal abilities of total nitrogen $(\mathrm{N})$, total phosphorous $(\mathrm{P})$, potassium $\left(\mathrm{K}^{+}\right)$, and biochemical oxygen demand (BOD) in the horizontal subsurface flow (HSSF) CW. The study was carried out in the HSSF CW having gravel as substrate material and common reed (narkat, phragmites karka) as macrophyte. The CW treated domestic wastewater at an average flow rate of $8.64 \mathrm{~m}^{3} . \mathrm{d}^{-1}$. The first order removal rate constants were $0.015 \mathrm{~m}^{-1}$ $\left(0.200 \mathrm{~d}^{-1}\right)$ for total $\mathrm{N}, 0.035 \mathrm{~m}^{-1}\left(0.484 \mathrm{~d}^{-1}\right)$ for total $\mathrm{P}, 0.004 \mathrm{~m}^{-1}\left(0.052 \mathrm{~d}^{-1}\right)$ for $\mathrm{K}^{+}$, and $0.055 \mathrm{~m}^{-1}(0.753$ $\mathrm{d}^{-1}$ ) for $\mathrm{BOD}_{5}$. The influent concentration of total $\mathrm{N}$, total $\mathrm{P}, \mathrm{K}^{+}$, and $\mathrm{BOD}_{5}$ ranged from $60-100,11-13,34-48$, and 60-120 mg. $\mathrm{I}^{-1}$, respectively; effluent concentration from 35-55, 1-3, 31-38, and 4-20 mg. $\mathrm{I}^{-1}$, respectively. Average removal efficiencies of total $\mathrm{N}$, total $\mathrm{P}, \mathrm{K}^{+}$, and $\mathrm{BOD}_{5}$ were $50.5,75.5,15.0$, and $86.9 \%$, respectively. $\mathrm{CW}$ will be a promising option for wastewater treatment.
\end{abstract}

\section{Keywords}

BOD, Common reed, Gravel, Horizontal Subsurface Flow Constructed Wetland, Nutrients, Wastewater

\section{Introduction}

Direct discharge of wastewater into environment causes several problems such as waterborne infectious diseases, eutrophication, and decrease in dissolved oxygen (DO) of water (resulting in biologically dead sections). Nitrogen $(\mathrm{N})$, phosphorous $(\mathrm{P})$, and potassium $\left(\mathrm{K}^{+}\right)$are the essential elements for the growth of microorganisms, plants, and animals. So, these are also called the nutrients but the concentrations are quite higher in wastewater, causing environmental pollution. Therefore, it is necessary to treat wastewater prior to discharge into environment. The wastewater treatment process which is simple, easy to operate and maintain, and low cost will be applicable in most of the developing countries including Nepal (Uemura et al., 2016).

Constructed wetlands (CWs) are artificial engineered systems, designed and constructed to treat wastewater by utilizing the natural processes involving macrophytes, substrate, and microorganisms (Vymazal, 2014, Shuib et al., 2011).

CWs can remove organic matter, suspended solids, nutrients, and heavy metals from wastewater. CWs are low energy-consuming, environment-friendly 'green' technique (Lee et al., 2009, Wu et al., 2015), low cost, land-intensive, and less-operational and maintenance-requiring in comparison to conventional treatment systems. Therefore, $\mathrm{CW}$ is a suitable wastewater treatment option for small and poor communities in remote locations or decentralized areas (Wu et al., 2015, Brix, 1987, Njau et al., 2003). To the best of our knowledge, no research has investigated the removal abilities of the pollutants with the length of the horizontal subsurface flow (HSSF) CW.

The main objective of this study was to determine the pollutant/nutrient removal abilities of HSSF CW from domestic wastewater, for different pollutant such as $\mathrm{N}$, 
Table 1: Design input parameters for the Horizontal Subsurface Flow Constructed Wetland

\begin{tabular}{|c|l|r|l|}
\hline S.No. & Input Parameter & Quantity & Units \\
\hline 1 & Design Discharge $(\mathrm{Q})$ & 8 & $\mathrm{~m}^{3} . \mathrm{d}^{-1}$ \\
2 & Influent BOD $\left(\mathrm{C}_{i}\right)$ & 200 & $\mathrm{mg} \cdot 1^{-1}$ \\
3 & Effluent BOD $\left(\mathrm{C}_{e}\right)$ & 50 & $\mathrm{mg} \cdot 1^{-1}$ \\
4 & Reaction Rate Constant at $20^{\circ} \mathrm{C}\left(\mathrm{K}_{20}\right)$ & 0.6 & per day for BOD removal \\
5 & Hydraulic Conductivity for gravel $\left(\mathrm{K}_{s}\right)$ & 500 & $\mathrm{~m}^{-1}$ \\
6 & Porosity $(\eta)$ & 40 & $\%$ \\
7 & Bed Slope $(\mathrm{S})$ & 0.5 & $\%$ \\
8 & Average temperature of effluent in winter for proposed & 9 & ${ }^{o} \mathrm{C}$ \\
& location (T) & 1.06 & \\
9 & Correction Factor $\left(\theta_{20}\right)$ & \\
\hline
\end{tabular}

Table 2: Detailed description of the CW

\begin{tabular}{|c|c|c|}
\hline Components & Dimensions (m) & Remarks \\
\hline Settling tank & $4.20 \times 2.55$ & Brick masonry \\
\hline Horizontal bed & $42.00 \times 7.00 \times 0.45$ & Single bed \\
\hline Inlet & $110 \mathrm{~mm} \phi$ perforated pipe & \\
\hline Media & & \\
\hline Inlet and outlet apron & $40 \mathrm{~mm}-80 \mathrm{~mm}$ size gravels & $150 \mathrm{~mm}$ compacted clay, lined with PVC \\
\hline Filter media & $20 \mathrm{~mm}-30 \mathrm{~mm}$ size pebbles & geo-membrane sheet and $50 \mathrm{~mm}$ sand filling \\
\hline Effluent tank & $4.90 \times 2.2$ & Brick masonry \\
\hline Outlet pipe & $110 \mathrm{~mm} \phi$ HDPE pipe & \\
\hline Inspection ports & \multicolumn{2}{|c|}{$110 \mathrm{~mm} \phi$ vertical PVC pipe at an average c/c spacing of $1.25 \mathrm{~m}$} \\
\hline
\end{tabular}

$\mathrm{P}, \mathrm{K}^{+}$, and organic matter (biochemical oxygen demand [BOD]). Determination of pollutant removal abilities will add a rational design approach of HSSF CWs treating domestic wastewater.

\section{Materials and Methods}

\subsection{Design Considerations}

The CW was designed and constructed at Pulchowk Campus, Institute of Engineering, Tribhuvan University in 2010, with the assistance of KOICA (Korea International Cooperation Agency). Design input parameters and detailed description of the $\mathrm{CW}$ are shown in Table 1 and Table 2, respectively (Shrestha, 2012).

Schematic diagram of CW is shown in Figure 1.

\subsection{Wastewater Flow Regulation}

In this study, domestic wastewater from the nearby community was initially collected and allowed to settle in settling tank. Wastewater flow was regulated and fixed to be $8.64 \mathrm{~m}^{3} \cdot \mathrm{d}^{-1}$ throughout the experimental period, considering the average flow in the dry season.
Detention time in the CW (Eq. 1) for the flow was calculated to be 3.06 days.

$$
t=\frac{\eta L W d}{Q}
$$

where,

$$
\begin{aligned}
& \eta=\text { Porosity }=40 \% \\
& L=\text { Bed Length }=42 \mathrm{~m} \\
& W=\text { Bed Width }=7 \mathrm{~m} \\
& d=\text { Depth of flow }=0.225 \mathrm{~m} \text { (average depth) } \\
& Q=\text { Discharge }=8.64 \mathrm{~m}^{3} \cdot \mathrm{d}^{-1}
\end{aligned}
$$

\subsection{Collection and Analysis of Sample}

This study was started from January, 2017 for 6 months. Samples were taken twice a week from the inlet, port number 1, 2, 4, 9, 12, 15, 18, 21, 23, 24, 25, 29,30 , and 31 (or flow distance 0.7, 1.9, 4.35, 11.1, $15.1,18.7,22.5,26.35,28.9,30.1,31.2,35.7,37.3$, and $38.65 \mathrm{~m}$ from the inlet), at least 10 intermediate ports in each sampling. The $\mathrm{pH}$ was measured in laboratory, after each sampling by standard $\mathrm{pH}$ meter (Auto Deluxe pH Meter LT-10). Samples were stored 

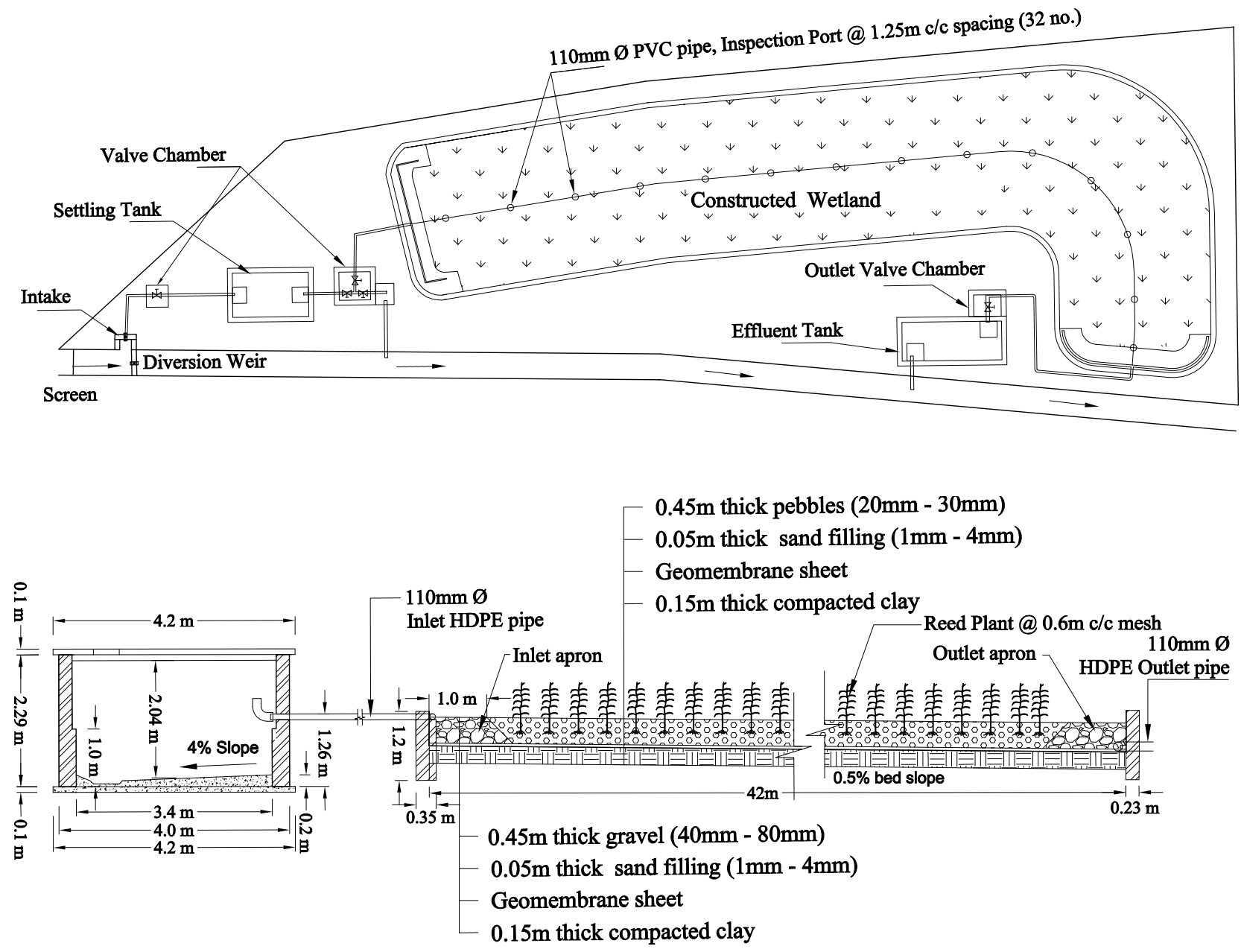

Settling Tank

Constructed Wetland

Figure 1: Schematic diagram (plan - top and section - bottom) of HSSF CW, constructed in the IOE premises

at $4{ }^{\circ} \mathrm{C}$ until the chemical analyses. Samples were analyzed in IOE laboratory in accordance with the standard methods for the examination of water and wastewater (APHA et al., 1999). Concentrations of total $\mathrm{N}$ and total $\mathrm{P}$ were measured by using Ultraviolet Spectrophotometric Screening method and Persulfate Digestion Method, respectively (UVmini - 1240, UV-VIS Spectrophotometer, Shimadzu Co. Ltd., Japan). $\mathrm{K}^{+}$was measured by Compact $\mathrm{K}^{+}$Meter B-731 (LAQUAtwin $\mathrm{K}^{+}$HORIBA Scientific). Five-day $\mathrm{BOD}\left(\mathrm{BOD}_{5}\right)$ was measured by the Winkler's iodometric method.

\subsection{Pollutant Removal Kinetics}

Previous studies suggested the use of first order kinetics model for the design of HSSF CW treatment systems (Kadlec, 2000, Rousseau et al., 2004). So, the pollutant removal rate $(\mathrm{K})$ of total $\mathrm{N}$, total $\mathrm{P}, \mathrm{K}^{+}$, and $\mathrm{BOD}_{5}$ in the HSSF CW were calculated based on the assumption that the nutrient removal follows first order kinetic reaction. First-order kinetic reactions for plug flow reactor is described by Eq. (2) (Metcalf and Eddy, 2003).

$$
\frac{d C}{d t}=-K . C^{1}=-K . C
$$

After integrating and simplifying, Eq. (2) reduces to Eq. (3).

$$
C_{t}=C_{o} e^{-K t}
$$

where,

$C_{t}=$ concentration at time, $\mathrm{t}$

$C_{o}=$ initial concentration, and

$t=$ time of flow 


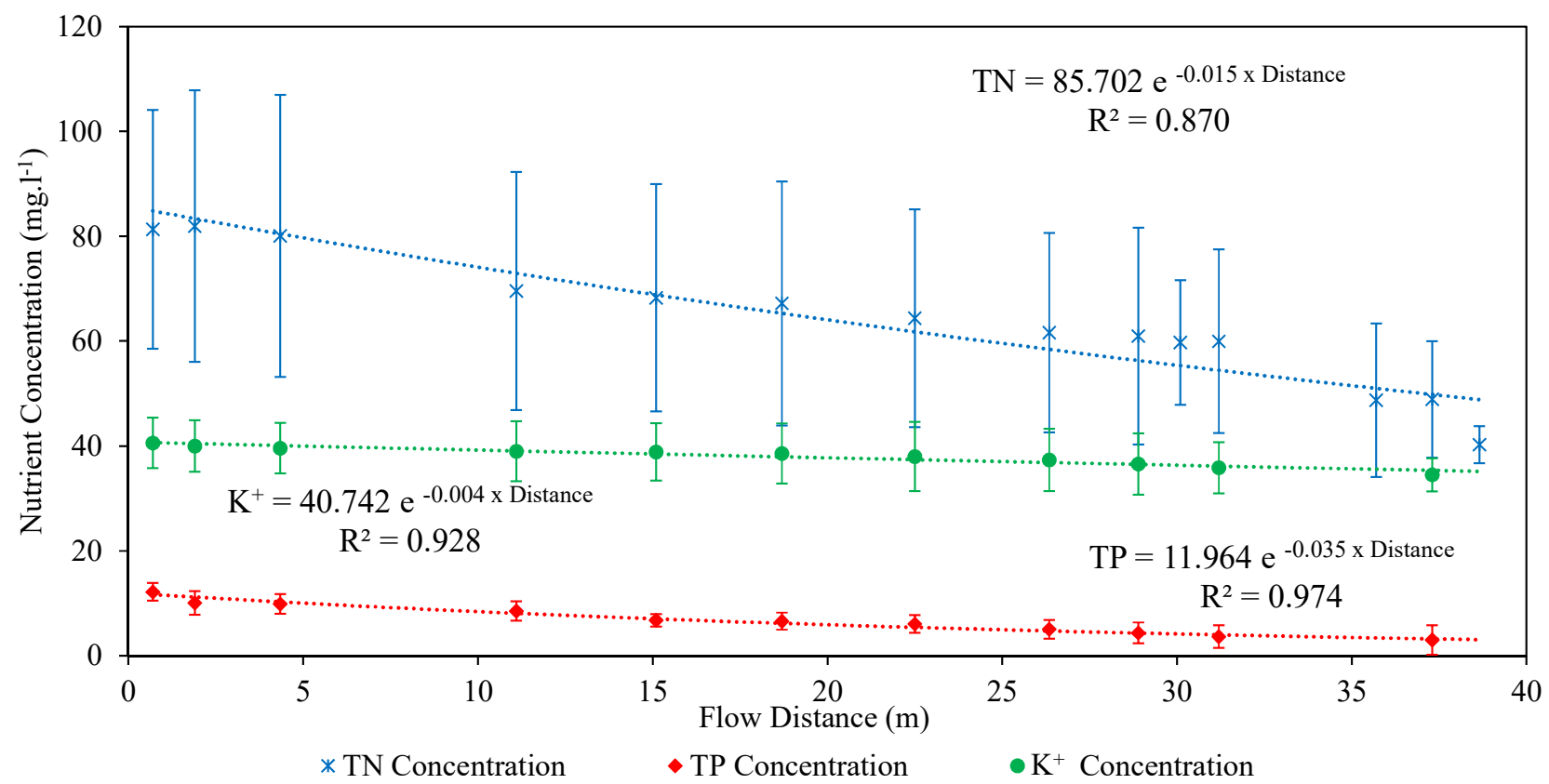

Figure 2: Nutrient concentration variations with respect to flow distance. Values represent means and the error bars indicate the standard deviations of the data

\section{Results and Discussions}

The performance of $\mathrm{CW}$ was measured in terms of total $\mathrm{N}$, total $\mathrm{P}, \mathrm{K}^{+}$, and $\mathrm{BOD}_{5}$ for the determination of their respective first order removal rates.

\subsection{Total Nitrogen Removal}

Total $\mathrm{N}$ concentration in the influent and the effluent samples were in the range of $60-100$ and $35-55$ mg. $1^{-1}$, respectively. Average removal efficiency of total $\mathrm{N}$ was $50.5 \%$. Total $\mathrm{N}$ variation pattern with respect to the length of $\mathrm{CW}$ is shown in Figure 2.

Concentration of total $\mathrm{N}$ was found to be gradually decreasing up to $30 \mathrm{~m}$ length of flow, which decreased at high rate afterwards. The first order removal rate constant of total $\mathrm{N}$ was $0.015 \mathrm{~m}^{-1}$ (Figure 2) or 0.200 $\mathrm{d}^{-1}$ (Figure 3).

In the first $5 \mathrm{~m}$ length of $\mathrm{CW}$, total $\mathrm{N}$ removal was less. Afterwards, the wastewater might have received oxygen from the roots of the reed plant for nitrification, and simultaneous denitrification occurred at the bottom of the $\mathrm{CW}$, decreasing the total $\mathrm{N}$ concentration. Since average $\mathrm{pH}$ of the influent was 7.7, the ammonium nitrogen removal by volatilization was insignificant (Reddy et al., 1984). The $\mathrm{pH}$ of the water sample decreased after $30 \mathrm{~m}$ length indicates the occurrence of microbial nitrification in the wetland (Richardson and Watmough, 1999, Schmidt et al., 2003). The digestion of total $\mathrm{N}$ is still not complete within the length of the CW.

\subsection{Total Phosphorous Removal}

Concentration of total $\mathrm{P}$ in the influent and the effluent were in the range of $11-13$ and $1-3 \mathrm{mg} . \mathrm{l}^{-1}$, respectively. Average removal efficiency of total $\mathrm{P}$ was $75.5 \%$. HSSF CW have high potential for total $\mathrm{P}$ removal via adsorption and precipitation but washed gravel has very low capacity of sorption and precipitation (Vymazal, 2007). During long term operation of the $\mathrm{CW}$, soil and other debris deposited over the gravel. This might have even decreased the sorption capacity of gravel.

Concentration of total $\mathrm{P}$ was found to be gradually decreasing up to $19 \mathrm{~m}$ length of flow, which decreased at high rate afterwards (Figure 2). The first order removal rate constant of total $\mathrm{P}$ was $0.035 \mathrm{~m}^{-1}$ (Figure 2) or $0.484 \mathrm{~d}^{-1}$ (Figure 3).

\subsection{Potassium Removal}

Potassium is an alkali metal required for the growth of plants and microorganisms. The influent concentration of $\mathrm{K}^{+}$ranged from 34 to $48 \mathrm{mg} . \mathrm{l}^{-1}$ and the effluent from 31 to $38 \mathrm{mg} \cdot \mathrm{l}^{-1}$. Average removal efficiency of $\mathrm{K}^{+}$was $15.0 \%$. $\mathrm{K}^{+}$variation pattern with respect to the length of $\mathrm{CW}$ is shown in Figure 2.

Concentration of $\mathrm{K}^{+}$was found to be gradually 


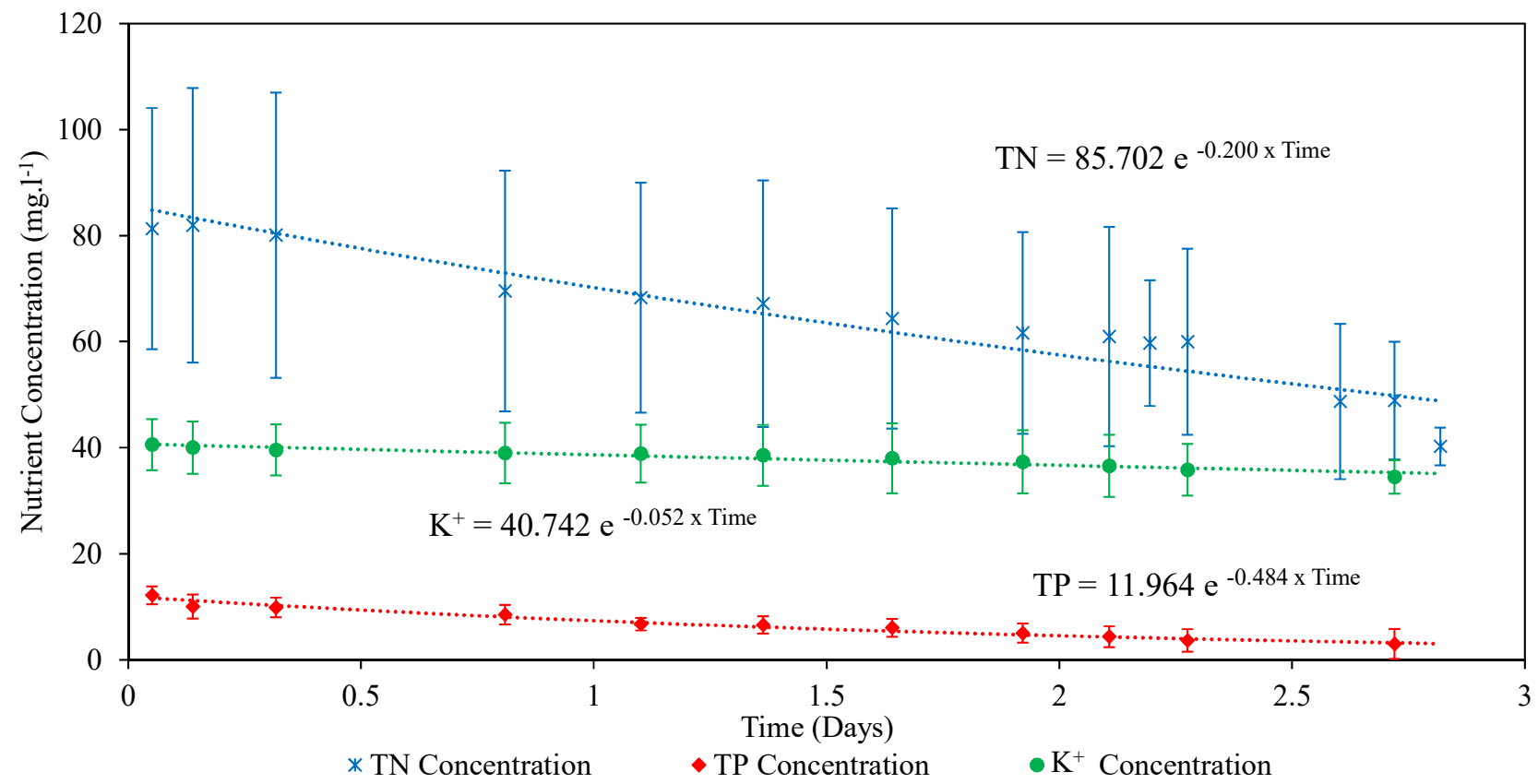

Figure 3: Nutrient concentration variations with respect to time. Values represent means and the error bars indicate the standard deviations of the data

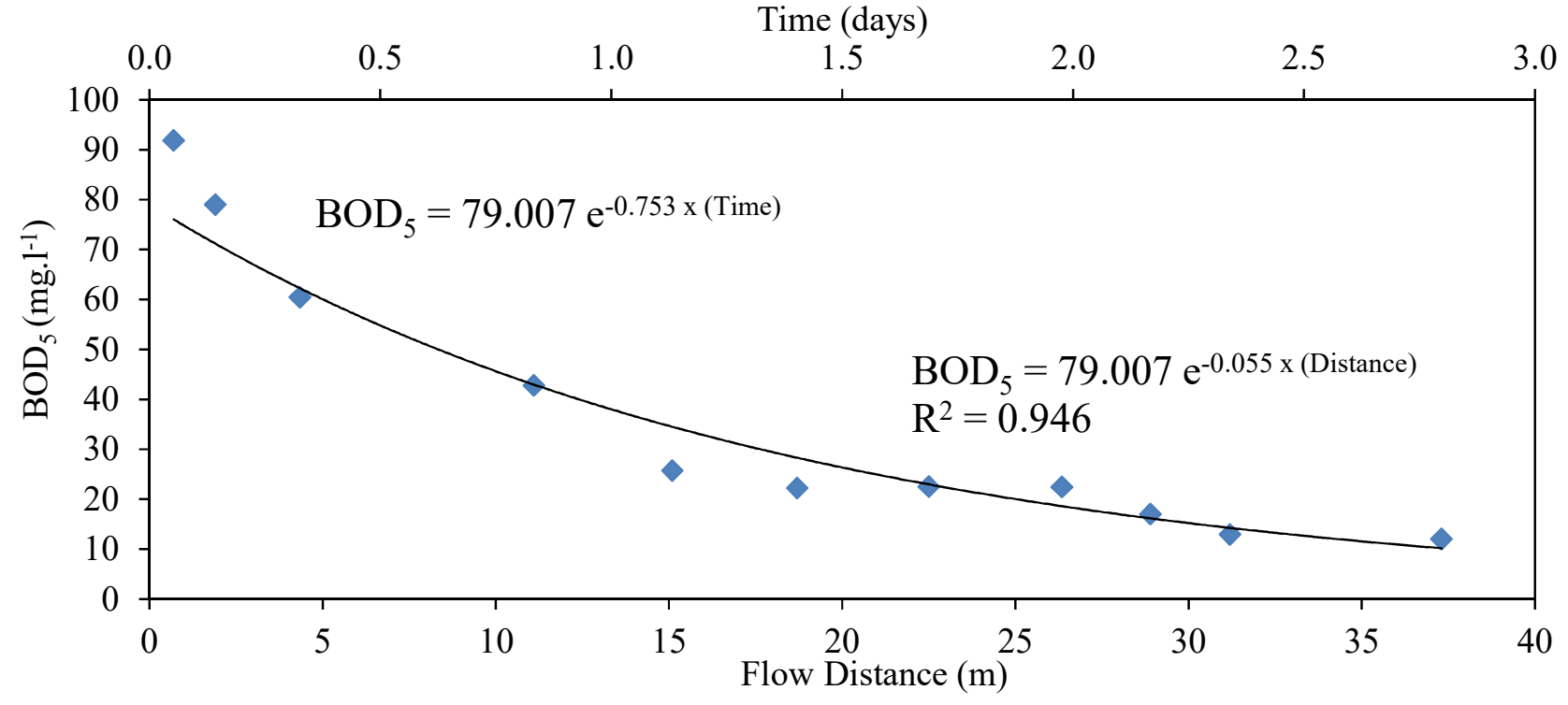

Figure 4: Variation in $\mathrm{BOD}_{5}$ with respect to flow distance (and time of flow, in secondary axis) in the $\mathrm{CW}$

decreasing up to $18 \mathrm{~m}$ length of flow, which decreased at high rate afterwards. The first order removal rate constant of $\mathrm{K}^{+}$was $0.004 \mathrm{~m}^{-1}$ (Figure 2) or 0.052 $\mathrm{d}^{-1}$ (Figure 3). $\mathrm{K}^{+}$removal rate / efficiency in CW was less in comparison to other studied parameters. Design of $\mathrm{CW}$ systems has not yet targeted $\mathrm{K}^{+}$ removal and efficiency is also very low (Kadlec and Wallace, 2008). Adsorption of $\mathrm{K}^{+}$on the gravel (substrate) and plant uptake could be the $\mathrm{K}^{+}$removal mechanism in wetlands. The length of $\mathrm{CW}$ seems to be insufficient for the $\mathrm{K}^{+}$removal and also may have been affected by decreased plant density in the $\mathrm{CW}$.

\subsection{Biochemical Oxygen Demand (BOD) Removal}

BOD is the most widely used parameter to determine the organic pollution, which involves the measurement of the dissolved oxygen (DO), consumed by microorganisms in the biochemical oxidation of organic matter present in the wastewater or the surface water. Presently, the BOD results are considered as the design parameter to determine the size of wastewater treatment facilities, to measure the efficiency of treatment processes, and to determine 
compliance with wastewater discharge permits (Metcalf and Eddy, 2003). $\mathrm{BOD}_{5}$ of the wastewater should be below $50 \mathrm{mg} \cdot \mathrm{l}^{-1}$ to discharge into inland surface waters (MOE, 2010). $\mathrm{BOD}_{5}$ in the influent and effluent wastewater were in the range of 60 - 120 and $4-20 \mathrm{mg} . \mathrm{l}^{-1}$, respectively, with an average removal efficiency of $86.9 \%$. Hence, the effluent meets the disposal standard for $\mathrm{BOD}_{5}$.

$\mathrm{BOD}_{5}$ was decreasing in the wastewater with the flow distance or time of flow in the CW (Figure 4). The oxygen release from the roots of the wetland plants contribute for the reduction of BOD of the water flowing in the wetlands (Dong et al., 2016). In addition, the possible reasons could be the consumption of organic matter present in wastewater by the microorganisms and plants, present in the system, biological degradation, and filtration/sedimentation. The first order removal rate constant for $\mathrm{BOD}_{5}$ was found to be $0.055 \mathrm{~m}^{-1}$ or $0.753 \mathrm{~d}^{-1}$. The result shows that the decrease in $\mathrm{BOD}_{5}$ after $30 \mathrm{~m}$ length was very low, so, it can be interpreted as the complete digestion of BOD within the length.

\section{Conclusions}

The variation pattern of the pollutants $\left(\mathrm{N}, \mathrm{P}, \mathrm{K}^{+}\right.$, and $\mathrm{BOD}_{5}$ ) with respect to the flow distance or time of flow in the $\mathrm{CW}$ was investigated. The first order removal rate constants were $0.015 \mathrm{~m}^{-1}\left(0.200 \mathrm{~d}^{-1}\right)$ for total $\mathrm{N}, 0.035 \mathrm{~m}^{-1}\left(0.484 \mathrm{~d}^{-1}\right)$ for total $\mathrm{P}, 0.004$ $\mathrm{m}^{-1}\left(0.052 \mathrm{~d}^{-1}\right)$ for $\mathrm{K}^{+}$, and $0.055 \mathrm{~m}^{-1}\left(0.753 \mathrm{~d}^{-1}\right)$ for $\mathrm{BOD}_{5}$. The influent concentration of total $\mathrm{N}$, total $\mathrm{P}, \mathrm{K}^{+}$, and $\mathrm{BOD}_{5}$ ranged from $60-100,11-13,34-48$, and 60-120 mg. $\mathrm{l}^{-1}$, respectively; effluent concentration from 35-55, 1-3, 31-38, and 4-20 mg. $1^{-1}$, respectively. Average removal efficiencies of total $\mathrm{N}$, total $\mathrm{P}, \mathrm{K}^{+}$, and $\mathrm{BOD}_{5}$ were $50.5,75.5,15.0$, and $86.9 \%$, respectively. Pollutant/nutrient removal rates in HSSF CW will provide an essential information for a rational design of HSSF CWs.

\section{Acknowledgments}

The authors express sincere thanks to Mrs. Prabha Karmacharya and Dr. Anil Aryal for their continuous support. Also, are grateful to the KOICA for constructing the wetland model in the IOE premises.

\section{References}

APHA, AWWA and WEF (1999). Standard Methods for Examination of Water and Wastewater, 20th edn, APHA, Washington DC, USA.

Brix, H. (1987). Treatment of wastewater in the rhizosphere of wetland plants-the root-zone method, Water Science and Technology 19(1-2): 107-118.

Dong, C., Huang, Y.-H., Wang, S.-C. and Wang, X.-H. (2016). Oxygen supply and wastewater treatment in subsurface-flow constructed wetland mesocosm: Role of plant presence., Polish Journal of Environmental Studies 25(2).

Kadlec, R. H. (2000). The inadequacy of first-order treatment wetland models, Ecological Engineering 15(1-2): 105-119.

Kadlec, R. H. and Wallace, S. (2008). Treatment wetlands, CRC press.

Lee, C.-g., Fletcher, T. D. and Sun, G. (2009). Nitrogen removal in constructed wetland systems, Engineering in Life Sciences 9(1): 11-22.

Metcalf and Eddy (2003). Wastewater Engineering: Treatment and Reuse, 4th edn, Tata McGraw-Hill Publishing Company Limited, New Delhi, India.

MOE (2010). Environmental Guidelines and Collection of Related Information, Kathmandu, Ministry of Environment, Government of Nepal (Original in Nepali), Kathmandu, Nepal.

Njau, K. N., Minja, R. J. and Katima, J. H. (2003). Pumice soil: a potential wetland substrate for treatment of domestic wastewater, Water Science and Technology 48(5): 85-92.

Reddy, K., Patrick, W. and Broadbent, F. (1984). Nitrogen transformations and loss in flooded soils and sediments, Critical Reviews in Environmental Science and Technology 13(4): 273-309.

Richardson, D. J. and Watmough, N. J. (1999). Inorganic nitrogen metabolism in bacteria, Current opinion in chemical biology 3(2): 207-219.

Rousseau, D. P., Vanrolleghem, P. A. and De Pauw, N. (2004). Model-based design of horizontal subsurface flow constructed treatment wetlands: a review, Water research 38(6): 1484-1493. 
Schmidt, I., Sliekers, O., Schmid, M., Bock, E., Fuerst, J., Kuenen, J. G., Jetten, M. S. and Strous, M. (2003). New concepts of microbial treatment processes for the nitrogen removal in wastewater, FEMS microbiology reviews 27(4): 481-492.

Shrestha, S. K. (2012). Nutrient removal in Horizontal Flow bed Constructed Wetland, $\mathrm{PhD}$ thesis, Institute of Engineering, Tribhuvan University, Nepal.

Shuib, N., Baskaran, K. and Jegatheesan, V. (2011). Evaluating the performance of horizontal subsurface flow constructed wetlands using natural zeolite (escott), International journal of environmental science and development 2(4): 311-315.

Uemura, S., Okubo, T., Maeno, K., Takahashi, M., Kubota, K. and Harada, H. (2016). Evaluation of water distribution and oxygen mass transfer in sponge support media for a down-flow hanging sponge reactor, International Journal of Environmental Research 10(2): 265-272.

Vymazal, J. (2007). Removal of nutrients in various types of constructed wetlands, Science of the total environment 380(1-3): 48-65.

Vymazal, J. (2014). Constructed wetlands for treatment of industrial wastewaters: a review, Ecological Engineering 73: 724-751.

Wu, H., Zhang, J., Ngo, H. H., Guo, W., Hu, Z., Liang, S., Fan, J. and Liu, H. (2015). A review on the sustainability of constructed wetlands for wastewater treatment: design and operation, Bioresource technology 175: 594-601. 
